\title{
PSYCHE.
}

\section{NOTES UPON THE TRANSFORMATIONS OF SOME AFRICAN LEPIDOPTERA.}

By W. J. HOI.lAND, PH.D., PITTSBURGH, PENN.

From among the mass of material illustrating the life-history of various species of West-African lepidoptera in my possession, and for which I am largely indebted to my indefatigable coadjutor, Mr. Good, I have culled a few notes, which are likely to prove interesting to the student of entomology. I have in all cases sought to elucidate by presenting sketches of the objects themselves, which I have drawn at moments of leisure, and which may be relied upon to do even more than the verbal accounts which I herewith give to make the subject plain.

\section{Saturnia arnobia Westw.}

In the Proceedings of the Zoological society of London for the year i 88I, p. I42, Prof. Westwood described a large bombycid moth to which he gave the name Saturnia arnobia. The specimen upon which he based his description came from Old Calabar, and is in the collection of T. Chapman, Esqr., Glasgow.

From Mr. Good I have received several males which correspond in the main with the figure and description of Prof. Westwood, who does not, by the by, indicate the sex of his type. The females differ quite materially from the males, and there is evidently a dry season brood, which differs in both sexes quite considerably from the wet season form. But the most remarkable fact in the life history of this great moth, which equals in expanse of wing the largest Bombycidae of North America, is the fact that the chrysalis is suspended, and while the caterpillar weaves a few stout silken threads about the spot where it undergoes its transformations, the chrysalis hangs pendulous from its support like the chrysalis of the Nymphalidae. This is best understood from the figure given upon Plate 5.

Before giving a description of the various forms of the species, I give the notes sent me by the collector :-

"No. 43. This number designates a very large moth which emerged from a very large chrysalis. The first of these large chrysalids was handed to me at Elovi, a town fifteen miles down the river from Kangwe. This chrysalis has not yet disclosed the imago, (May 14 th, 
I 888). Two weeks or more afterwards (April 30), I obtained six more chrysalids at the same place, and one of the flies which had come out in the hands of the natives and is not perfect. One of the lot secured upon April 3oth came out during the night of May I 2 th and damaged itself slightly before I discovered it. I send it in the envelope marked 43, and the empty pupa-case in a box marked with the same number. Is not this an anomaly? I have never before obtained a moth from a chrysalis hanging suspended as this one was. When I got the chrysalis first I thought now I have the chrysalis of Papilio antimachus or zalmoxis, and I'll get the female sure. I had been led to suppose from my reading that chrysalids so suspended and comparatively unprotected always produce diurnal butterflies. The chrysalis is dark green in color, beginning to change before disclosing the moth to a pale green, and later to the yellow of the empty shell."

Mr. Good sent me of this brood six perfect specimens, male and female, and several chrysalids which had failed to disclose the imago, and from one of which the figure on Plate 5 is drawn. Later he sent me three of the second brood, and a chrysalid, which in form is identical with the chrysalids of the first brood, but smaller. This last sending was accompanied by the following note :-

"No. 43. - I designate these specimens by the same mark, No. 43 , as those which I sent you in the summer. The chrysalid appears to be identical in form and color, but the moths are very different in color. If this is the same species then the larvae bred in the dry season do not produce as fine moths as those that feed in the latter part of the rainy season. These specimens emerged Oct. I5th, I888, the rainy season, which is late this year, having just commenced."

Rainy season brood. $\delta$. Not differing materially from the figure and description of Prof. Westwood. The ground color is a bright yellow, with the darker markings ochraceous rufous. Expanse 6 I-2 inches.

. Wings very broad, and not nearly as pointed at apex as in the male. General color tawny ochraceous, with darker markings deep burnt sienna. Expanse of wings 7-7 $\mathrm{I}-4$ inches.

Dry season brood. The general color of the two sexes is the same, and may be described as Mars brown, with the darker markings of a livid purplish cast. Expanse of wings: $\delta, 43-4$ inches; $q 5-5 \mathrm{I}-2$ inches.

\section{IDIOMORPHUS VALA Ploetz.}

Under this name Dr. Ploetz described from a single female a species of Idiomorphus (genus of Satyridae,) which had been collected by Dr. Buchholz upon the West African coast. T'he species is very common upon the Ogové River, at all events $I$ have received from Mr. Good many scores of examples, male and female. The larval stages of this genus, which is peculiar to the hottest parts of tropical Africa, have 
never been described, as far as I am aware. Unfortunately the inflated caterpillar of the species did not turn up in the sending in which it was included. Whether it was destroyed by the carelessness of custom-house officials, or in some other way was lost, I do not know. The chrysalids sent me by $\mathrm{Mr}$. Good came safely to hand and are outlined upon Plate 5. In speaking of the habits of the larva the collector says :-

"The larvae are very peculiar looking creatures, gregarious, feeding sparingly upon a low and very coarse grass, which grows in open ground and forms great bunches. The leaf of this grass is from a foot to a foot and a half in length, and from an inch to an inch and a half in width. When not feeding these caterpillars are always to be seen on the under side of the leaf, lying together as closely as possible, and presenting a very queer appearance. They increase in size very slowly. The chrysalids I send you were suspended from the lid of the box, but in nature they hang from the underside of a leaf or blade of grass. The first of the butterflies emerged Dec. 24th, and the last Dec. 29th. The time during which they remain in the pupal state is about a week."

There are five species of Idiomorphus which are found at Kangwe, of which the species before us seems to be the most common. They are the following :-
I. vala Ploetz.
I. hewitsonii Doumet.

I. italus Hewitson.

I. zinebi Butler.

I. sebetus Hewitson.

Of the latter species I have thus far received but a single specimen. It appears to be the rarest of the five.

\section{Harma caenis Drury.}

Of this species Mr. Good sends me an inflated larva, and several chrysalids, from which the figures on Plate 5 are taken.

The female of this species is polymorphic. There is a female which very closely resembles the male, and in fact cannot be separated from it, except by an examination of the sexual organs. This form is not common. I have but one specimen. Then there is a dark female, which is the common form and is figured accurately in Staudinger's work upon the Exotic Butterflies, and was also figured by Cramer as Harma amphiceda. Then there is still another form in which the basal area of both wings upon the upper side is more or less suffused with red. Both of these latter forms are before me bred in numerous examples from the same batch of larvae.

In a letter received from $\mathrm{Mr}$. Good several years ago he stated that this species is in the habit of migrating in great swarms. Apropos of his account of the migration of Harma caenis the following note giving some details as to the migration of another species may not be inappropriately reproduced here.

"Oct. I4th, I89o. To-day at Batanga I saw Crenis amulia flying in great 
Psyche, 1892, Vol. 6.

Plate 5
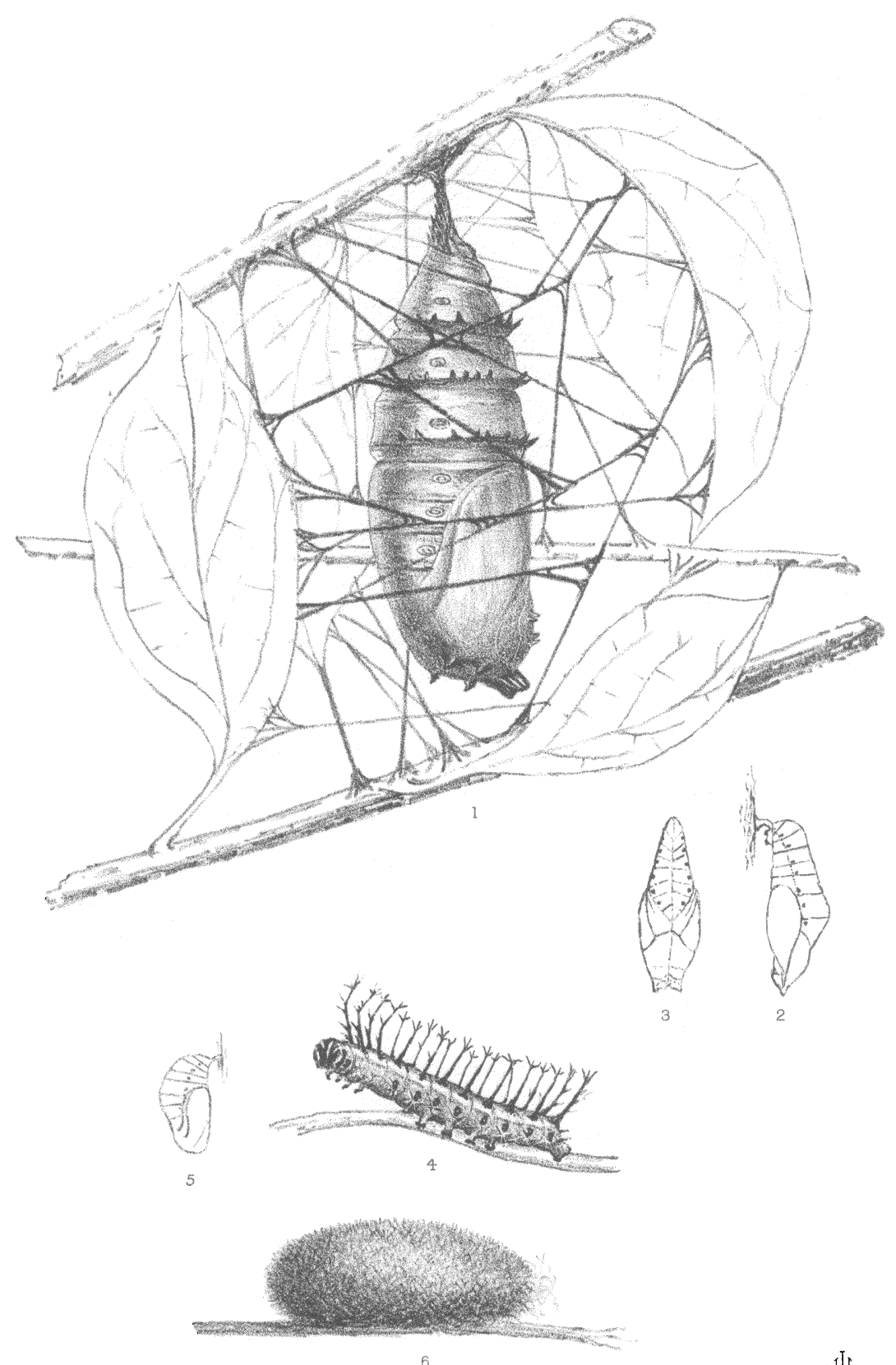
swarms just as some years ago I saw Harma caenis in the Ogové region. They seemed to come from nowhere in particular, they flew in no order, no two even keeping company. Sometimes only a dozen were visible, at other times hundreds seemed to fill the air. They flew a little E. of N. E. This has no particular significance, however, as this is the general direction of the coast here. Even upon the beach the migratory movement was easily observed, and as far as I went back, (about half a mile) the air seemed full of the flies. None were returning, and all flew as if they had a definite purpose in view. A native remarked it, and ventured, in calling my attention to the movement to add 'Sometimes they fly so, and sometimes they fly in the opposite direction." "...

"I am utterly at a loss to account for the phenomenon. The explanation which I suggested for the migration of Harma caenis, which this exactly resembles, will not apply here. That took place near the end of the dry season and was toward the approaching rains. But here the rains are frequent now, and if these flies are seeking anything to northward it must be dry weather."

\section{Chrysopsyche mirifica Butler.}

I have received from $\mathrm{Mr}$. Good several specimens of this exceedingly beautiful bombycid, and also a specimen of the cocoon, which is very tough and dark chocolate brown in color and studded all over as are many of the cocoons of the African Bombycidae with minute spines, which are derived from the epidermis of the caterpillar. The figure upon Plate 5 will serve better than a description to give an idea of the form of the cocoon.

EXPLANATION OF PLATE 5.

Fig. I. Chrysalis of Saturnia arnobia Westw.

Fig. 2. Chrysalis of Idiomorphus vala Ploetz. (lateral view).

Fig. 3. Chrysalis of Idiomorphus vala Ploetz. (dorsal aspect).

Fig. 4. Larva of Harma caenis Drury. Fig. 5. Chrysalis of "6

Fig. 6. Cocoon of Chrysopsyche mirifica Butler.

\section{CONCERNING THE "BLOOD-TISSUE" OF THE INSECTA.-I.}

BY WILLIAM MORTON WHEELER, WORCESTER, MASS.

Hitherto little attention has been devoted to the study of the blood, fat-body, and allied structures in insects. We have extensive monographs on the eyes and other sense-organs, on the muscu- lature and nervous system, and even on the alimentary tract and its various subdivisions, but few serious attempts have been made to fill the gaps in our knowledge of the physiologically highly im- 

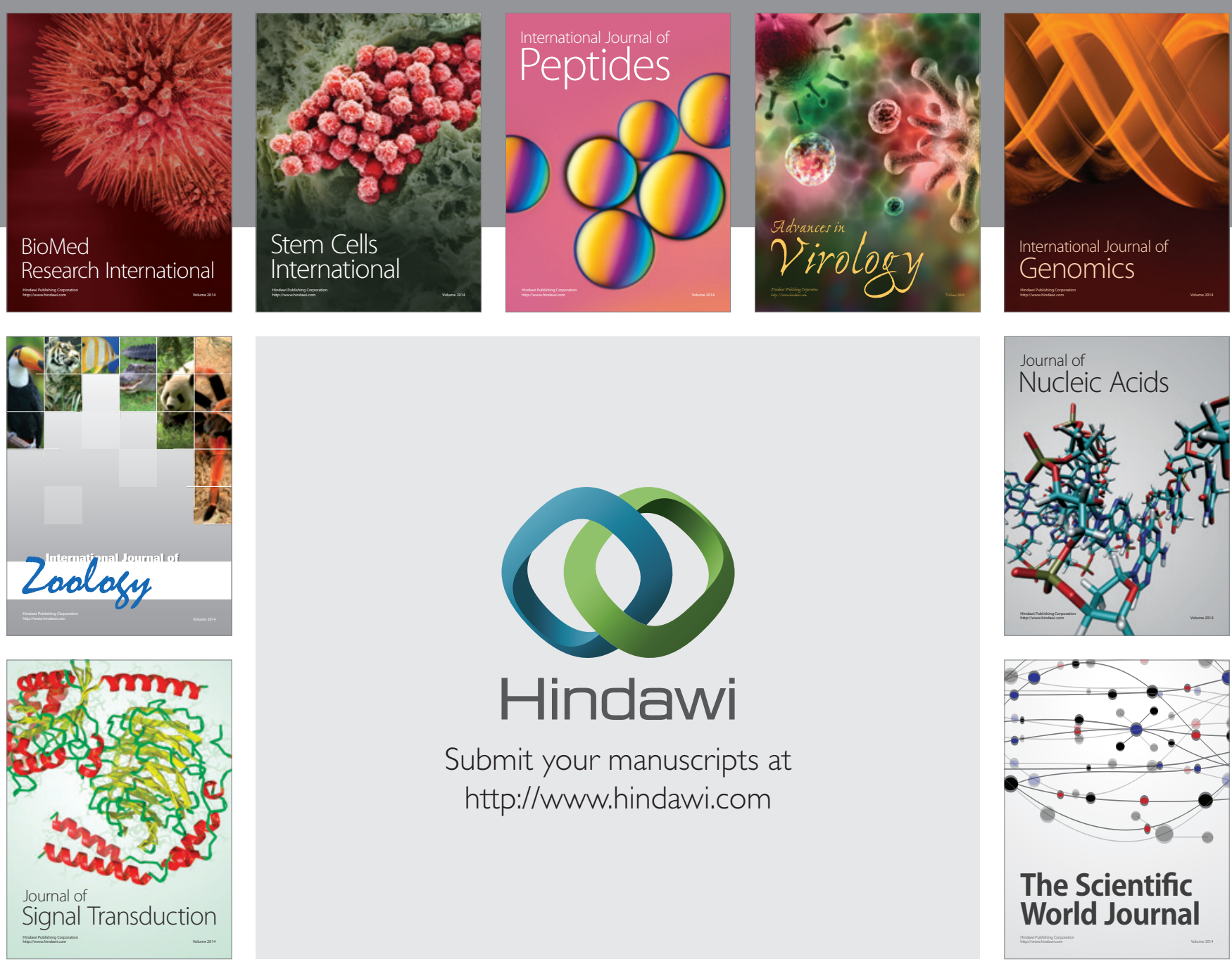

Submit your manuscripts at

http://www.hindawi.com
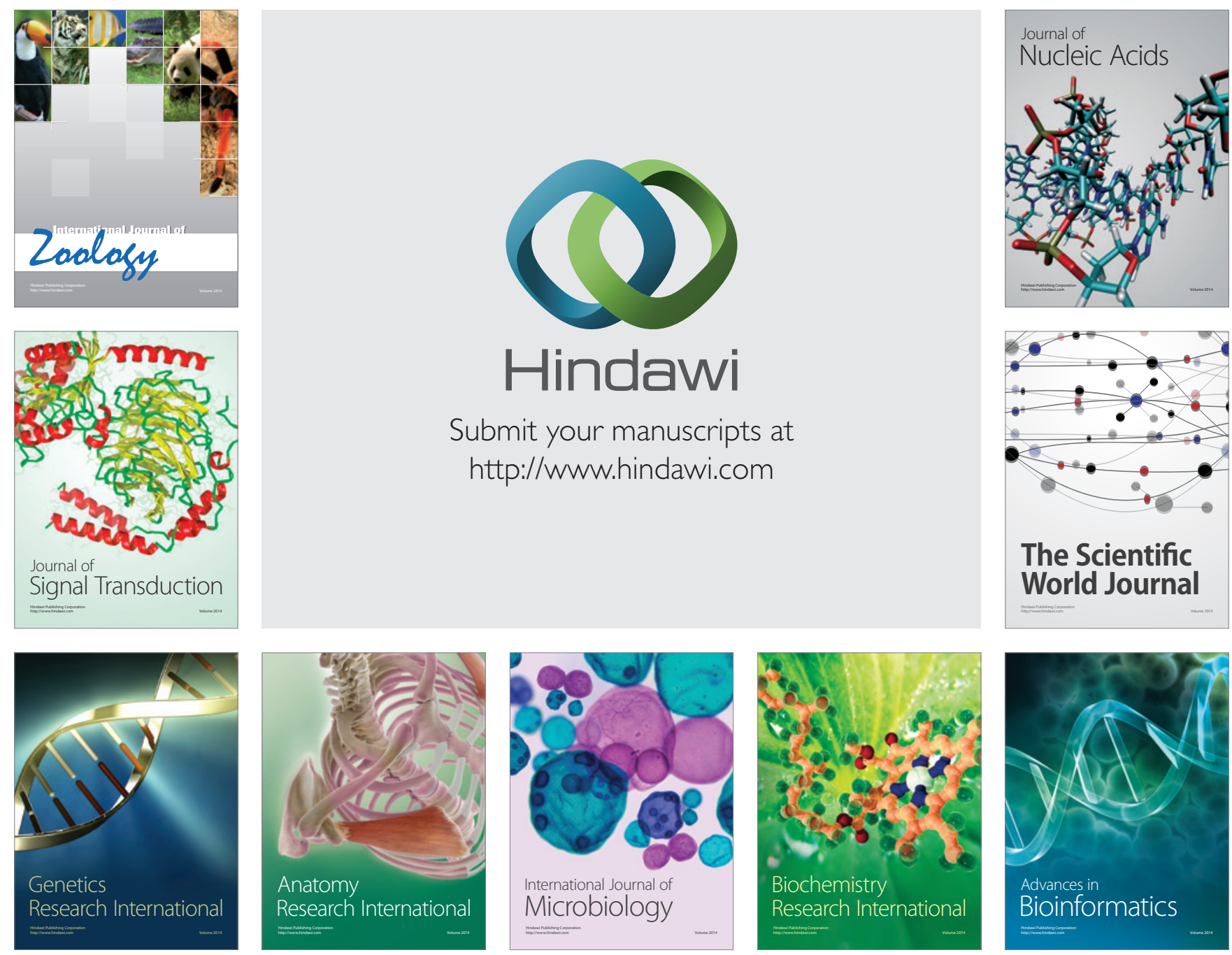

The Scientific World Journal
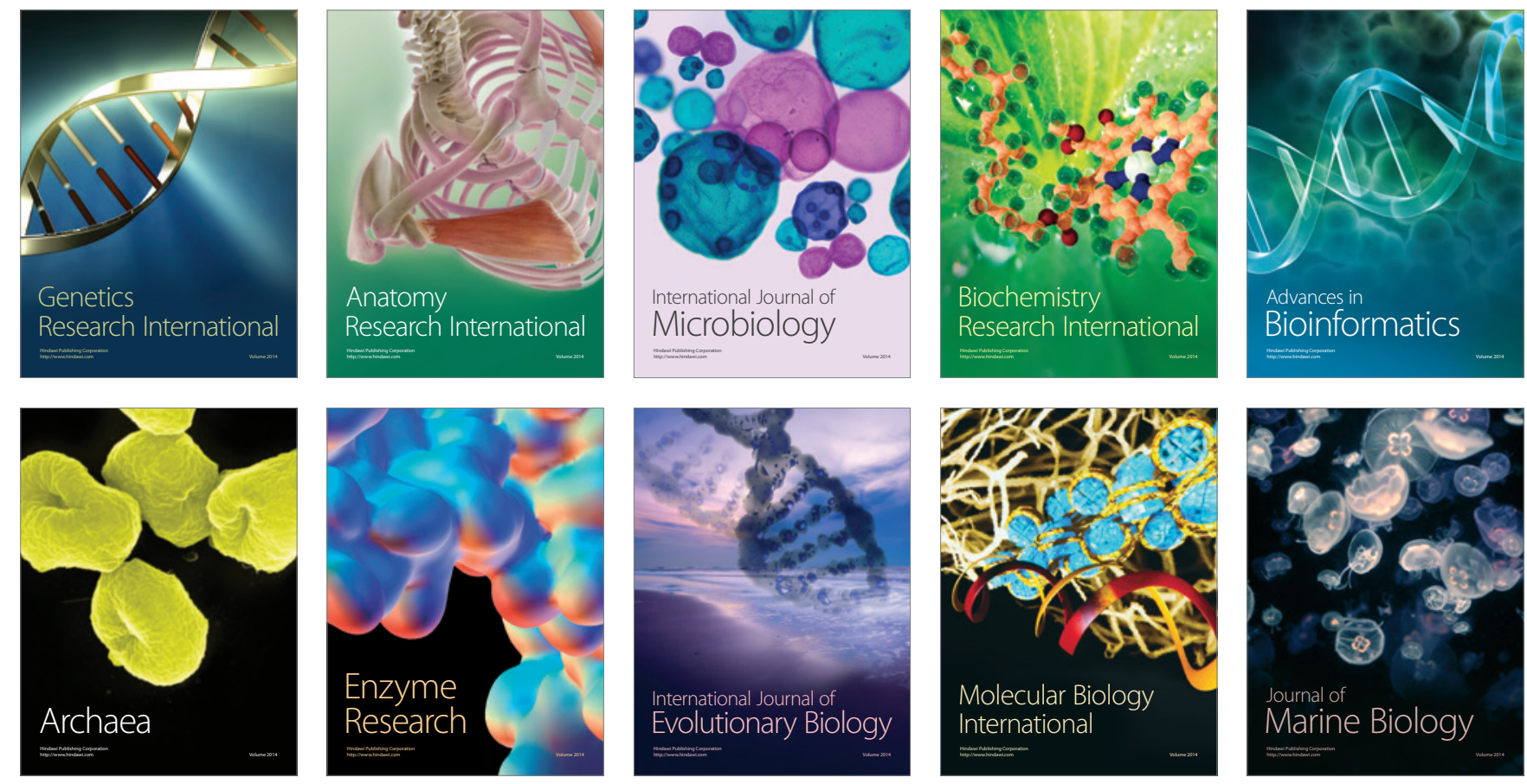